\title{
Evaluation of the Impact of Using Electronic Marketing in Marketing Illegal Products by Applying to Marketing of Digital Drugs in the Kingdom of Saudi Arabia
}

\author{
Abeer Elsayed Fayed ${ }^{1 / 2}$ \\ ${ }^{1}$ Marketing Department, Tabouk University, Kingdom of Saudi Arabia \\ ${ }^{2}$ Academy of Specialized Studies, Egypt \\ Correspondence: Abeer Elsayed Fayed, Marketing Department, Tabouk University, Kingdom of Saudi Arabia. \\ E-mail: abeerfayed2@gmail.com
}

Received: November 28, 2018

Accepted: December 30, 2018

Online Published: January 25, 2019

doi:10.5539/ijbm.v14n2p66

URL: https://doi.org/10.5539/ijbm.v14n2p66

\begin{abstract}
Just as electronic marketing has advantages, it also has its disadvantages. Through it, illegal products can be marketed, which are prosecuted by governments in traditional markets. These products have found a safe haven in the electronic marketing to market them. One of these products is drugs, which are a major threat to any government and fought against by it. Therefore, its marketers have circumvented this situation and turned them into digital addiction fighting the young people known for their keen interest in the Internet.

The study observed the misuse and illegal use of electronic marketing. Thus, the problem of the study was the spread of marketing illegal products through the Internet, such as digital drugs, exploiting the spread and popularity of electronic marketing, especially among adolescents and young people.

The study used the descriptive analytical approach. It was also based on the simple correlation coefficient and the stepwise regression coefficient to test hypotheses for one of the methods included in the SPSS.

The study concluded that there was a strong relationship between the use of electronic marketing components and the spread of digital drugs. Without electronic marketing, there would be no presence of this type of drugs. It also found the skill of their marketers in using the marketing mix components to market their deadly product. The study also found the possibility of using the means of curbing the spread of these drugs via electronic means over the Internet and in the same way of their marketers. Finally, the study concluded that this harmful marketing could affect the future of electronic marketing; rather, the electronic commerce as a whole.

The study recommended the use of the electronic counter-promotion strategy against these websites in line with raising awareness of young people, blocking websites promoting them, and prosecuting them if created again, penetrating the websites marketing the digital drugs and change their content. A comprehensive national plan that includes the Ministries of Health, Education, Interior and Justice is needed.
\end{abstract}

Keywords: electronic marketing, electronic counter-promotion, digital drugs, electronic addiction, illegal products, electronic marketing websites of digital drugs

\section{Introduction}

The amazing technological revolution has brought about many advantages and benefits to the world, which has helped it to progress in all directions. In the recent past, it has brought about the electronic commerce, including the electronic marketing, which has had a positive impact on our lives. However, with its rapid spread, illegal trade has begun to resort to and exploit it to market its products prosecuted continuously by governments. The more governments are successful in counteracting these products marketed in traditional ways, the more marketers of these products develop their ways to market their illegal products. Recently, drug marketers have found their haven in electronic marketing, as it is difficult to prosecute them despite the efforts exerted by governments with their technological means to confront them. However, the marketers succeed every time in facing this, because of the many technological loopholes they are using.

The marketers of these illegal products (such as digital drugs) have exploited the interest of young people (especially in the Arab world) in the Internet, and their fancy to experimentation and buying from it. They started 
exporting their electronic toxins at low prices, which lead to addiction more quickly than conventional drugs, destroying brain cells and possibly leading to death.

The digital drugs flow through ears in the form of tones up to the brain to affect its normal waves to make the abusers in a relaxed condition. This type is traded online at low prices and its products take the form of audio files (mp3). They are first downloaded free on trial. This often achieves its purpose; the listener addicts it and reorder it. To enjoy the music, the listener must relax, close his eyes, put a wrap on them and turn off all electrical devices that disturb or confuse listening. He must wear loose clothes and wear high definition headphones on his ears (so that he can distinguish between sounds and their degrees). He then plays the audio file, and this music provides the speakers with sounds like waves and muffled sounds. The sound strength is between 1000: $1500 \mathrm{~Hz}$ so he can hear the beats. The effect of the drug happens by providing the two ends of the headphones with two different sound frequencies and the difference is slight, about $30 \mathrm{~Hz}$. This difference is the determinant of the dose volume. The greater the difference is, the dose increases. It has many types such as conventional drugs and holds the same names of conventional drugs, each by its effect. It has more new types. (Rouse, 2018; Hardy \& Norgaard, 2016; Décary-Hétu \& Giommoni, 2017; Demant, Munksgaard, Houborg, 2016).

The danger of digital drugs is that addiction can occur unintentionally, taking advantage of the existence of a great leisure time among young people, their fancy of the Internet and their love for experimentation. These websites offer narcotic music as a kind of ordinary music. Even more dangerous, there can be some websites offering youth advice against these drugs. Their purpose is that young people try these drugs and then addict them. This has already happened to many young people, so it is necessary to reveal this subject and closely recognize it. The young people must be introduced and aware of it so as not to fall prey to it. The youth of the Kingdom like the rest of the Arab youth has become a target of these sites. We all must unite to save our youth. This research is a simple contribution to this purpose. (Martin, 2016; Buskirk, Roxburgh, Bruno, Lenton, Naicker, \& Burns, 2016; Dong, 2014; Connolly, 2018; Aldridge \&Décary-Hétu, 2014).

\subsection{Research Questions}

With the spread of electronic marketing and its popularity over time, especially by young people, the marketers of illegal products turned to it as a hidden way to market their products. The governments cannot prosecute them for their technological capability and their ability to hide online. They use aliases, identity-hiding programs, and encrypted currencies on payment.

The electronic market has become a popular market for many illegal products that are spreading more rapidly than traditional markets around the world. One of these products is digital drugs, which are the modern development of traditional drugs and are suitable for electronic use. Therefore, the problem of research is represented in the following questions:

RQ1: Does the electronic marketing (represented in the marketing mix components) have an effective role in the spread of Illegal products such as digital drugs?

RQ2: Are there ways to spread of Illegal products such as digital drugs without electronic marketing?

RQ3: Is there a relationship between the means of curbing the electronic marketing of Illegal products such as digital drugs and their spread?

RQ4: How does digital drug addiction happen through electronic marketing?

RQ5: Will the spread of Illegal products such as digital drug marketing websites lead to distrust in electronic marketing and electronic commerce as a whole in the future?

\section{Literature Review}

Little literature has addressed this topic, most of which were foreign studies.

The websites marketing digital drugs promote them using some arguments and false claims, such as that they do not contain chemicals, and that they do not affect the body (Curtis \& Wendel, 2014). They are also promoted as they make their users feel relaxation or excessive movement and energy (Crespo, Recuero, Galvez, \& Begona, 2016), awakening inert memory (Kennel, Taylor, Lyon, Bourguignon, 2014), sense of happiness, imagination and inspiration, all without alcohol or headache.( Connolly, 2018).

They were presenting an electronic catalog of their products to promote them (Barratt, Ferris, \& Winstock, 2016). They also promoted supplemental addiction tools as a form of sales promotion through offers such as special speakers, eye covers, etc. (Bancroft \& Reid, 2016). It also found that these websites used very strong advertising policies to attract customers of different ages but they focus more on young people. (Christin, 2015). 
Digital drug marketers marketed the kinds shown on the website for a small amount of money first, using promotional pricing and a market penetration policy to their knowledge that young people and children did not have the financial ability to pay large sums (Bingham, 2015). After taking them for the first time and visiting these websites again, prices are a bit more expensive (Tzanetakis, 2015). However, on some websites,[45] they give them to customers free of charge until they ask for them again and again, after which it will be for a high consideration (Martin, 2017).

digital drug marketers marketed their existing kinds through the website, but if a customer wanted a new type, they produced for him according to his order and according to the type of impact he wanted and made him addicted (Hough, 2014). This could happen in the advanced stages of addiction and for a larger financial consideration (Franceschi \& Pearson, 2016). The name of the product from digital drugs carried the same names as conventional drugs to indicate the type of addiction that the digital drug type causes, such as its counterpart in conventional drugs (Dolliver, 2017), so that the product itself is used as a trademark for it. The studies also showed that they also offered assistive products for full addiction and offered an important product, a booklet that explained how to use this music to get the desired, of relaxation, exhilaration, alertness and attention, etc. (Gwern, 2017).

As for distribution, the distribution of digital drugs was carried out entirely through the Internet and through several media based on the websites promoting digital drugs (Coomber, \& Moyle, 2014), but often through social media (Buxton \& Bingham, 2015). It was also done through YouTube videos, (Burns, Roxburgh, Bruno, \& Van Buskirk, 2014) which were often free. Color effects were performed to cause a higher status of addiction to the abuser (Aldridge \& Décary-Hétu, 2014).

Digital drugs were a type of drug in which the narcotic substance affecting the mental and psychological aspects were transformed from its physical, liquid or gaseous form into a new form by downloading these drugs into electronic or digital containers in files (Tzanetakis, 2018). The file could form the narcotic dosage with the effect that might be equivalent to the same effect as conventional drugs in the functioning of the brain and chemical and nervous reactions and in mental and neurological condition (Bingham, 2015).

Digital drugs are a set of digital or electronic effects that affect the human nerve cells through sound files not balanced at the same time affecting the center of the human balance (McConnell, Froeliger, Garland, Ives, Sforzo, 2014), affecting the nerve cells and spinal cord and leading to the entry of the person in a negative situation leading to the behavior of the addicted person (Pratt, Starr, Michalewski, Dimitrijevic, Bleich, \& Mittelman, 2014). The digital drugs are the next threat to young people because of the large use of the Internet, its applications and the extent to which young people are connected to technology (Bingham, 2015).

The damage caused by digital drugs and its destructive effects especially when used repeatedly (Kennel, Taylor, Lyon, \& Bourguignon, 2014). They affect the nervous system; they have an impact on the level of awakening and concentration, especially among young people and adolescents (Akeroyd, 2015). They also affect the normal development of the nervous system of children and young people as well. The studies also show that digital drugs also cause memory disorders. They also have an impact on the proper perception of addicts as conventional drugs do (Atteya, 2016). The studies also show that digital drugs affect the level of awakening and concentration of abuser. They affect the normal development of the nervous system among children and young people up to the age of 25 years (Crespo, Recuero, Galvez, \& Begona, 2016).

Taking digital drugs leads to the emergence of mental disorders and illness (Brady, Stevens, 2014; Huang \& Charyton, 2014). Contrary to what the websites promoting digital drugs, they influence student performance and achievement. They do not help to increase creativity in arousing attention and lead to departure from reality (Abu Srea Ahmed \& Abdul Rahman, 2017; Atteya, 2016; El Hayari, 2018; Habib, 2015). The change in mood depended on the type of digital drug. There were some types leading to dizziness and relaxation (Ferris, Barratt, \& Winstock, 2014), and some leading to concentration and attention (Isak, 2017; Smith, 2018). This is not a good thing, given the consensus of all studies that they have negative effect on cognitive functions of the abuser's brain (El Jabouri \& Abdul Hussein, 2015).

The targeting of the Kingdom of Saudi Arabia, concluded that the Kingdom was targeted by digital drugs. Thus, its young people were the most vulnerable to digital drug addiction in the world because they widely used the Internet and social media. The study showed that the rate of active Internet users in Saudi Arabia was estimated at $86 \%$ of the population per day. Mobile Internet users were amounted to $61 \%$ of the population. The young people were $70 \%$ of the Kingdom's population. This means that young people from 20: 25 years were targeted 
by modern means of communication; therefore, the most important disadvantages, which were digital drugs (Dunya al-Watan, 2018).

\subsection{Brief of Literature}

From the previous literature, there has been a clear lack of dealing with the subject. Some studies focused on a simple part of the subject, such as the studies that dealt with how to deal with the product, the studies that dealt with how to determine the price or which dealt with the method of promotion. No Arabic Study dealt with the marketing mix completely and no study dealt with how to face these websites at the marketing level, There is also no study on the impact of marketing these illegal products on the future of electronic commerce. Therefore, there is a great lack of these points and this will be dealt with in the present study.

\section{The Hypotheses}

The websites marketed for illicit products such as digital drugs use marketing mix with great skill. They display the product through the Internet, promote it. Connolly (2018) Develop the product and produce it according to the customers' request (Martin, 2016). It also uses the Internet in distribution, with no disclosure of its identity for the purpose of not being able to reach it (Morgan, 1970). Appropriate pricing methods are used for this category of young people who do not have Enough money (Buskirk, Burns, Roxburgh, \& Farrell, 2017).

On this I can formulate the first hypothesis, and its sub-clauses as follows:

H1: There would be a statistically significant relationship between the use of the electronic marketing mix components of Illegal products such as digital drugs and their spread in the Saudi society.

\section{This hypothesis is divided into several sub-hypotheses:}

H1a: There would be a statistically significant relationship between the use of the electronic product of Illegal products such as digital drugs and their spread in the Saudi society.

H1b: There would be a statistically significant relationship between the use of the electronic pricing of Illegal products such as digital drugs and their spread in the Saudi society.

H1c: There would be a statistically significant relationship between the use of the electronic promotion of Illegal products such as digital drugs and their spread in the Saudi society.

H1d: There would be a statistically significant relationship between the use of the electronic distribution of Illegal products such as digital drugs and their spread in the Saudi society.

One of the tools that is effective in overcoming the marketing of illicit products such as digital drugs is the use of counter-promotion, because it works to educate customers against these sites and fight their lies (Hough, 2016). On this I can formulate the Scond hypothesis, and its sub-clauses as follows:

H2: There would be a statistically significant relationship between the use of the electronic counter-promotion against of Illegal products such as digital drugs and their spread in the Saudi society.

These products are likely to affect the future of e-marketing and possibly e-commerce as a whole, as customers may lose confidence in the entire tool (Crespo, Recuero, Galvez, \& Begona, 2016). Accordingly, the third assumption would be:

H3: There would be a statistically significant relationship between the spread of electronic marketing websites of Illegal products such as digital drugs and the future of electronic marketing in the Saudi society.

\section{The Study Variables}

From the above, a set of required variables were identified to verify the validity or invalidity of the study hypotheses and to reach a proper interpretation of the study problem. They have been divided into:

The Independent Variables: Electronic product of Illegal products such as digital drugs; electronic pricing of Illegal products such as digital drugs; electronic promotion of Illegal products such as digital drugs; electronic distribution of Illegal products such as digital drugs; electronic counter-promotion against of Illegal products such as digital drugs; spread of electronic marketing websites of Illegal products such as digital drugs.

The Dependent Variables: The spread of Illegal products such as digital drugs; the future of electronic marketing.

\subsection{Objectives of the Study}

In the light of the study problem, the research aims to achieve the following objectives: 
1. To identify the role of electronic marketing (especially the components of marketing mix) in the spread of Illegal products such as digital drugs in the Saudi society.

2. To identify the best ways of electronic counter-promotion against of Illegal products such as digital drugs in the Saudi society.

3. To clarify how the spread of Illegal products such as digital drugs affects the future of electronic marketing in the Saudi society.

\subsection{Significance of the Study}

The significance of the study stems from scientific significance and practical significance as follows:

\subsection{The Scientific Significance}

The scientific significance is due to the scarcity of Arab research on the subject of electronic marketing and its relationship to Illegal products such as digital drugs and the impact of these drugs on young people. Rather, this research is one of the first researches on examining this subject.

\subsection{The Practical Significance}

The study derives its practical significance from the following:

1. This study deals with the illegitimate aspect of technology, the Internet and electronic marketing, which in itself has become an addiction to the Saudi youth and is exploited by the visitors of these websites to spread their deadly poison to our promising youth.

2. This study reviews how marketing mix components are used in the spread and marketing of illegal products.

3. This research deals with the subject of drugs, which is very important for its great impact on human health, especially this new type of drugs, digital drugs, which has targeted our youth.

4. To helping anti-drug officials in the Kingdom to know how to curb the electronic marketing of digital drugs and to prevent the negative impact of electronic marketing.

5. To make use of this study to educate the Saudi youth against these deadly drugs.

\section{Methodology}

\subsection{Research Design}

This study is descriptive as it describes the status of illegal products, including digital drugs, how to curb their spread, their relationship to electronic marketing and its impact on it the future. The most important aspects of the problem were identified and the problem was properly identified. The secondary data were collected to identify the previous studies that addressed the subject, then complete the points that were not covered by these studies and properly determine the hypotheses of the study. The raw data were collected to identify the validity or invalidity of the study hypotheses and thus to reach the conclusions and recommendations of the study.

\subsection{The Study Population}

The study population is all the youth in the headquarters of the University of Tabuk (approximately 30,000 students).

\subsection{The Study Sample}

The sample size was determined according to the Morgan's Table (Morgan, 1970), as the appropriate number of the unknown population is 379 units. Based on Morgan's sample size table, the sample size was 379 units.

An electronic questionnaire was distributed through an electronic link to all the social media of the students of Tabuk University. The stratified sampling method was used, where there were two subpopulations, namely, the male students' population and the female students' population. The number of returned forms was approximately 420 , of which 395 were valid, 379 of which were selected taking into consideration the percentage of male students and the percentage of female students in selecting the correct forms.

\subsection{The Type and Sources of Data Collection}

Two types of data were used:

\section{A. The Secondary data:}

Secondary data was obtained through researches, books, publications, reports, references and theses that dealt with this subject, to create a sound theoretical background on the research subject. 


\section{B. The Raw Data ( Questionnaire design data collection):}

The raw data were obtained from the study population, by distributing an electronic form. The electronic form was selected for several reasons, that is, the problem concerns digital drugs, and thus, the Internet users were targeted. It was of the reasons that the visitors or who were familiar with these websites would respond without fear and freely without knowing their identities. Finally, it was because it was difficult to identify who visited these websites or even to who were familiar with them (as they are the targeted group in question). An electronic form was distributed, and it was noted that whoever answered this form was a person who were visiting these websites or even familiar with their content through going to them even once.

And the variables were measured through the closed-ended, pre-defined questions. The researcher also used the five-point Likert scale as a way to measure the respondents' opinions on the variables in question. It is composed of 5 points (where weight 5 refers to Agree Absolutely and weight zero to Not Agree At All). The researcher relied on a set of statements obtained from previous studies and exploratory study.

\subsection{Data Analysis}

The study relied on some statistical methods included in the SPSS. They were the simple correlation coefficient; the stepwise regression coefficient (in which each independent variable was entered sequentially, where we knew which independent variables were more influential in the dependent variable, then we knew the variable that followed influentially and then the next and so on until the variables with effect ended and the variables with no effect were excluded from the analysis); t-test; F-Test; R2, coefficient of determination; as well as some descriptive statistics analyses.

\section{Results}

\subsection{The Descriptive Analysis of Data}

The results of the descriptive analysis show that $92 \%$ of the respondents reported that digital drugs were traded through electronic marketing. The results showed that the respondents were familiar with digital drugs through the Internet at $89 \% ; 6 \%$ knew them through friends, 3\% knew them through relatives, and $2 \%$ knew them through the media. The results also showed that $70 \%$ of the respondents said that they were frequent buyers and repeated buying from the Internet, and that $30 \%$ did not repeat or never repeated buying from the Internet. The results showed that $100 \%$ of the sample reported that digital drugs were traded via the Internet. That $80 \%$ of the sample preferred to address the electronic promotion of digital drugs, and only $20 \%$ did not see it necessary. As for the possibility of buying digital drugs from outside the Internet, $100 \%$ of the sample thought that this could not be done. The sample believed that digital drugs were purchased only from the Internet.

\subsection{Analyzing the Hypotheses Results}

\subsubsection{Testing the First Hypothesis}

H1: There would be a statistically significant relationship between the use of the electronic marketing mix components of illegal products such as digital drugs and their spread in the Saudi society.

The stepwise regression analysis was used to test this hypothesis with all its sub-hypotheses in order to identify the relationship between the independent variable and the dependent variable. It was also to identify which independent variables were more influential in the dependent variable and then the next, followed by the next, and so on.

\section{This hypothesis is divided into several sub-hypotheses}

H1a: There would be a statistically significant relationship between the use of the electronic product of illegal products such as digital drugs and their spread in the Saudi society.

Table (1) annexed indicates that the combined independent variables explains $86 \%$ of the change in the electronic product use of digital drugs. It is a statistically significant percentage at a significant level 0.000 . The remaining percentage is due to other independent variables and random error. The variable of "the product name has a large role in determining the product" has the greatest impact on the dependent variable, followed by the variable of "the website is a trademark of the product," and then "the production is sometimes according to the formula desired by the customer," etc.

The results of t-test indicates that all the variables are significant, except the variable of "obtaining information about customers through the website," and the variable of "the website is designed so that the consumer feels that he is directed to him personally," they both have no significance. Thus, they have no effect on the dependent variable. The correlation coefficient of $90 \%$ indicates a very strong and positive correlation between the 
electronic product of digital drugs and the spread of digital drugs. The results thus showed a strong and positive correlation between the (independent variable) electronic product of digital drugs and the (dependent variable) the spread of digital drugs.

Table 1. Results of the stepwise regression analysis of the sub-hypothesis I of the first hypothesis

\begin{tabular}{|c|c|c|c|c|c|c|}
\hline Independent Variables & $\mathbf{R}$ & $\mathbf{R}^{2}$ & $\mathbf{F}$ & Sig. F & $\mathbf{t}$ & Sig. $\mathbf{t}$ \\
\hline $\begin{array}{l}\text { - The product name has a significant } \\
\text { role in determining the desired product. }\end{array}$ & 0.712 & 0.641 & 231.125 & 0.000 & -1.954 & 0.000 \\
\hline $\begin{array}{l}\text { - The website is a trademark of the } \\
\text { product. }\end{array}$ & 0.740 & 0.695 & 205.213 & 0.000 & 2.258 & 0.042 \\
\hline $\begin{array}{l}\text { - Production is sometimes done } \\
\text { according to the formula desired by the } \\
\text { customer. }\end{array}$ & 0.761 & 0.728 & 181.928 & 0.000 & 1.987 & 0.038 \\
\hline $\begin{array}{l}\text { - Customer information is obtained } \\
\text { through the website. }\end{array}$ & 0.784 & 0.749 & 132.526 & 0.000 & -1.521 & 0.225 \\
\hline $\begin{array}{l}\text { - The website contains additional } \\
\text { information on how to maximize the } \\
\text { benefit of using digital drugs. }\end{array}$ & 0.801 & 0.782 & 102.862 & 0.000 & -1.981 & 0.010 \\
\hline $\begin{array}{l}\text { - The website is designed so that the } \\
\text { consumer feels that he is directed to him } \\
\text { personally. }\end{array}$ & 0.831 & 0.816 & 80.654 & 0.000 & 1.025 & 0.154 \\
\hline $\begin{array}{l}\text { - An electronic catalog of digital } \\
\text { drug types is displayed. }\end{array}$ & 0.863 & 0.834 & 87.358 & 0.000 & -0.852 & 0.035 \\
\hline $\begin{array}{l}\text { - Information about each type of } \\
\text { digital drugs and purpose of their use are } \\
\text { displayed. }\end{array}$ & 0.887 & 0.850 & 78.369 & 0.000 & -1.024 & 0.049 \\
\hline $\begin{array}{l}\text { - The transaction is completely done } \\
\text { through the website. }\end{array}$ & 0.897 & 0.861 & 68.369 & 0.000 & 0.831 & 0.044 \\
\hline
\end{tabular}

The dependent variable: spread of digital drugs.

Source: The table prepared by the researcher from the results of statistical analyses.

H1b: There would be a statistically significant relationship between the use of the electronic pricing of illegal products such as digital drugs and their spread in the Saudi society.

Table 2. Results of the stepwise regression analysis of the sub-hypothesis II of the first hypothesis

\begin{tabular}{lllllll}
\hline Independent Variables & $\mathbf{R}$ & $\mathbf{R}^{2}$ & $\mathbf{F}$ & Sig. F & t & Sig. t \\
\hline$-\quad$ Promotional prices are initially used. & 0.645 & 0.523 & 138.259 & 0.000 & -2.112 & 0.000 \\
$-\quad$ The high pricing policy is used after & 0.718 & 0.613 & 115.698 & 0.000 & 1.258 & 0.029 \\
$\begin{array}{l}\text { first use. } \\
-\quad \text { Prices are placed on the website for }\end{array}$ & -0.756 & 0.687 & 103.965 & 0.000 & 1.367 & 0.018 \\
$\begin{array}{l}\text { each product of digital drugs. } \\
-\quad \text { Flexible price policy is used. }\end{array}$ & 0.784 & 0.717 & 98.786 & 0.000 & -1.896 & 0.025 \\
$-\quad \begin{array}{l}\text { Pricing is according to supply and } \\
\text { demand. }\end{array}$ & 0.815 & 0.775 & 73.987 & 0.000 & -1.238 & 0.610 \\
$-\quad$ Low pricing policy is used. & 0.829 & 0.810 & 69.756 & 0.000 & 1.098 & 0.023 \\
\hline
\end{tabular}

The dependent variable: spread of digital drugs

Source: The table prepared by the researcher from the results of statistical analyses.

Table 2 annexed indicates that the combined independent variables explains $81 \%$ of the change in the electronic pricing use of digital drugs. It is a statistically significant percentage at a significant level 0.000 . The remaining percentage is due to other independent variables and random error. The variable of "the use of promotional prices in the beginning" is the most important independent variable affecting the dependent variable, followed by 
the variable of "the high price policy is used after first use," then the variable of "the prices are placed on the website for each product of digital drugs," then the variable of "the flexible price policy is used," and finally the variable of "the low price policy is used." The t-test results indicate that all variables are significant, except for the variable of "pricing is according to supply and demand," it has no significance. Therefore, it has no effect on the dependent variable.

The correlation coefficient of $82 \%$ indicates a very strong and positive correlation between the electronic pricing of digital drugs and the spread of digital drugs. The results thus showed a strong and positive correlation between the (independent variable) electronic pricing of digital drugs and the (dependent variable) the spread of digital drugs.

H1c: There would be a statistically significant relationship between the use of the electronic promotion of illegal products such as digital drugs and their spread in the Saudi society.

Table 3. Results of the stepwise regression analysis of the sub-hypothesis III of the first hypothesis

\begin{tabular}{|c|c|c|c|c|c|c|}
\hline Independent Variables & $\mathbf{R}$ & $\mathbf{R}^{2}$ & $\mathbf{F}$ & Sig. F & $\mathbf{t}$ & Sig. $t$ \\
\hline $\begin{array}{l}\text { - Websites are the largest promoters } \\
\text { of digital drugs. }\end{array}$ & 0.624 & 0.597 & 351.178 & 0.000 & -2.158 & 0.000 \\
\hline $\begin{array}{l}-\quad \text { Digital drugs are advertised via } \\
\text { websites. }\end{array}$ & 0.678 & 0.638 & 312.283 & 0.000 & 2.397 & 0.027 \\
\hline $\begin{array}{l}\text { - Websites promoting digital drugs } \\
\text { are spreading. }\end{array}$ & 0.707 & 0.602 & 261.928 & 0.000 & -1.987 & 0.039 \\
\hline $\begin{array}{l}\text { - The number of websites promoting } \\
\text { digital drugs is increasing over time. }\end{array}$ & 0.768 & 0.667 & 206.576 & 0.000 & 1.964 & 0.043 \\
\hline $\begin{array}{l}\text { - The digital drug manual is } \\
\text { promoted. }\end{array}$ & 0.793 & 0.698 & 189.522 & 0.000 & 1.729 & 0.023 \\
\hline $\begin{array}{l}\text { Tools necessary for digital drug } \\
\text { use is promoted. }\end{array}$ & 0.828 & 0.727 & 123.054 & 0.000 & -0987 & 0.042 \\
\hline $\begin{array}{l}\text { - The digital drugs are promoted by } \\
\text { using lies. }\end{array}$ & 0.887 & 0.784 & 97.568 & 0.000 & -0.382 & 0.029 \\
\hline $\begin{array}{l}\text { - Sales promotion methods are used } \\
\text { over the promoting sites. }\end{array}$ & 0.926 & 0.850 & 85.379 & 0.000 & -2.024 & 0.031 \\
\hline $\begin{array}{l}\text { - Conversations are held with } \\
\text { customers to build up strong relationships } \\
\text { with them through promoting sites. }\end{array}$ & 0.978 & 0.951 & 78.317 & 0.000 & 0.798 & 0.038 \\
\hline
\end{tabular}

The dependent variable: spread of digital drugs.

Source: The table prepared by the researcher from the results of statistical analyses.

Table 3 annexed indicates that the combined independent variables explains $93 \%$ of the change in the electronic promotion use of digital drugs. It is a statistically significant percentage at a significant level 0.000 . The remaining percentage is due to other independent variables and random error. The variable of "the websites are the largest promoter of digital drugs" have the greatest impact on the dependent variable, followed by the variable of "the digital drugs are advertised via websites," etc., the variables of the previous table. The t-test results indicate that all variables are significant. Thus, all have an effect on the dependent variable. The correlation coefficient of $95 \%$ indicates a very strong and positive correlation between the electronic promotion of digital drugs and the spread of digital drugs. The results thus showed a strong and positive correlation between the (independent variable) electronic promotion of digital drugs and the (dependent variable) the spread of digital drugs.

H1d: There would be a statistically significant relationship between the use of the electronic distribution of illegal products such as digital drugs and their spread in the Saudi society. 
Table 4. Results of the stepwise regression analysis of the sub-hypothesis IV of the first hypothesis

\begin{tabular}{|c|c|c|c|c|c|c|}
\hline Independent Variables & $\mathbf{R}$ & $\mathbf{R}^{2}$ & $\mathbf{F}$ & Sig. F & $\mathbf{t}$ & Sig. $t$ \\
\hline $\begin{array}{l}\text { - The Internet is the sole } \\
\text { distributor of digital drugs. }\end{array}$ & 0.655 & 0.612 & 263.487 & 0.000 & -1.103 & 0.000 \\
\hline $\begin{array}{l}\text { - Distribution is done over } \\
\text { designated websites. }\end{array}$ & 0.684 & 0.657 & 215.347 & 0.000 & -1.356 & 0.017 \\
\hline $\begin{array}{l}\text { Distribution is done through } \\
\text { social networking websites. }\end{array}$ & 0.702 & 0.692 & 189.147 & 0.000 & 1.856 & 0.029 \\
\hline $\begin{array}{l}\text { Distribution is done via } \\
\text { YouTube. }\end{array}$ & 0.761 & 0.720 & 1165.963 & 0.000 & -1.236 & 0.033 \\
\hline $\begin{array}{l}\text { - Websites are designed for } \\
\text { electronic payment methods. }\end{array}$ & 0.792 & 0.753 & 123.563 & 0.000 & 1.028 & 0.027 \\
\hline - Websites prepare the & & & & & & \\
\hline $\begin{array}{l}\text { methods of receiving the product } \\
\text { electronically. }\end{array}$ & 0.832 & 0.797 & 101.25 & 0.000 & 0.892 & 0.018 \\
\hline $\begin{array}{l}\text { - Direct distribution policy is } \\
\text { used over the Internet. }\end{array}$ & 0.879 & 0.823 & 98.245 & 0.000 & -0.645 & 0.009 \\
\hline $\begin{array}{l}- \\
\text { 24/7. }\end{array}$ & 0.907 & 0.864 & 89.254 & 0.000 & 2.105 & 0.003 \\
\hline $\begin{array}{l}\text { - Information is provided only } \\
\text { via the Internet. }\end{array}$ & 0.938 & 0.911 & 79.458 & 0.000 & 0.803 & 0.042 \\
\hline
\end{tabular}

The dependent variable: spread of digital drugs.

Source: The table prepared by the researcher from the results of statistical analyses.

Table 4 annexed indicates that the combined independent variables explains $91 \%$ of the change in the electronic promotion use of digital drugs. It is a statistically significant percentage at a significant level 0.000 . The remaining percentage is due to other independent variables and random error. The variable of "the Internet is the sole distributor of digital drugs" is the most important independent variable that affect the dependent variable, followed by the variable of "the distribution via the dedicated websites," etc., the variables of the previous table. The t-test results indicate that all variables are significant. Thus, all have an effect on the dependent variable. The correlation coefficient of $94 \%$ indicates a very strong and positive correlation between the electronic promotion of digital drugs and the spread of digital drugs. The results thus showed a strong and positive correlation between the (independent variable) electronic distribution of digital drugs and the (dependent variable) the spread of digital drugs.

\subsubsection{Testing the Second Hypothesis}

$\mathrm{H} 2$ : There would be a statistically significant relationship between the use of the electronic counter-promotion against of illegal products such as digital drugs and their spread in the Saudi society.

Table (5) annexed indicates that the combined independent variables explains $87.7 \%$ of the change in the electronic counter-promotion against digital drugs. It is a statistically significant percentage at a significant level 0.000 . The remaining percentage is due to other independent variables and random error. The variable of "the websites promoting digital drugs are to be blocked," followed by the variable of "promotion against websites promoting digital drugs by all electronic means" are the most important independent variables that affect the dependent variable.

The correlation coefficient of $90 \%$ indicates a very strong and positive correlation between the electronic counter-promotion against digital drugs and the curb of spread of digital drugs. The t-test results indicate that all variables are significant except the variables of blocking the promoting websites; the blackout and non-disclosure of digital drugs are not significant. The results showed a strong and positive correlation between the (independent variable) means of curbing the spread of digital drugs and the (dependent variable) curbing the spread of digital drugs. 
Table 5. Results of the stepwise regression analysis of the second hypothesis

\begin{tabular}{|c|c|c|c|c|c|c|}
\hline Independent Variables & $\mathbf{R}$ & $\mathbf{R}^{2}$ & $\mathbf{F}$ & Sig. F & $\mathbf{t}$ & Sig. t \\
\hline $\begin{array}{l}\text { - Websites promoting digital drugs are } \\
\text { to be blocked. }\end{array}$ & 0.868 & 0.754 & 354.736 & 0.000 & -2.254 & 0.000 \\
\hline $\begin{array}{l}\text { - Websites promoting digital drugs are } \\
\text { to be promoted by electronic means. }\end{array}$ & 0.873 & 0.801 & 184.985 & 0.000 & 2.088 & 0.036 \\
\hline $\begin{array}{l}\text { - Counter-promotional sites against } \\
\text { digital drugs are to be created. }\end{array}$ & 0.876 & 0.832 & 124.944 & 0.000 & 2.031 & 0.169 \\
\hline $\begin{array}{l}\text { - Digital drug risks are to be promoted } \\
\text { by all electronic means. }\end{array}$ & 0.880 & 0.851 & 96.556 & 0.000 & -1.627 & 0.047 \\
\hline $\begin{array}{l}\text { Websites promoting them are to be } \\
\text { penetrated and their content is to be } \\
\text { changed. }\end{array}$ & 0.881 & 0.863 & 77.854 & 0.000 & -2.041 & 0.009 \\
\hline $\begin{array}{l}\text { - Digital drug product names are to be } \\
\text { promoted. }\end{array}$ & 0.883 & 0872 & 65.631 & 0.000 & 1.521 & 0.184 \\
\hline $\begin{array}{l}\text { - Names of websites promoting digital } \\
\text { drugs are to be promoted. }\end{array}$ & 0.895 & 0.872 & 63.455 & 0.000 & -0.748 & 0.331 \\
\hline $\begin{array}{l}\text { - International cooperation is to } \\
\text { identify and prosecute the sources of } \\
\text { promoting websites. }\end{array}$ & 0.899 & 0877 & 57.682 & 0.000 & -1.109 & 0.853 \\
\hline $\begin{array}{l}\text { - There must be awareness to report the } \\
\text { promoting websites. }\end{array}$ & 0.901 & 0.878 & 52.068 & 0.000 & 0.831 & 0.894 \\
\hline
\end{tabular}

The dependent variable: spread of digital drugs.

Source: The table prepared by the researcher from the results of statistical analyses.

\subsubsection{Testing the Third Hypothesis}

H3: There would be a statistically significant relationship between the spread of electronic marketing websites of digital drugs and the future of electronic marketing in the Saudi society.

Table 6. Results of correlation and regression analysis of the third hypothesis

\begin{tabular}{llllll}
\hline $\mathbf{F}$ & & $\mathbf{t}$ & & $\mathbf{R}$ & $\mathbf{R}^{\mathbf{2}}$ \\
\hline Table & Calculated & Table & Calculated & \multirow{2}{*}{0.542} & \multirow{2}{*}{0.673} \\
\cline { 1 - 5 } 0.000 & 32.789 & 0.042 & 0.776 & & \\
\hline
\end{tabular}

Source: The table prepared by the researcher from the results of statistical analyses.

Table 6 annexed shows the correlation and regression results between the two variables. It is clear that there is a correlation relationship (approximately 54\% correlation coefficient) between the spread of digital drug promoting websites and the future of electronic marketing in the Saudi society. The independent variable explains approximately $67 \%$ of the change in the dependent variable. It is a statistically significant percentage at a significant level 0.000 , which is table $\mathrm{f}$ value. The remaining percentage is due to other independent variables and random error. It is clear from the table that the correlation between the variables is significant. The t-test results indicate that the spread of websites promoting digital drugs has a statistically significant impact on the future of electronic marketing in the Saudi society. Thus, it is clear that there is a positive correlation between the (independent variable) spread of digital drug promoting websites and the (dependent variable) the future of electronic marketing in the Saudi society.

\section{Finding}

The research results can be presented as follows:

The results of the study showed the strong influence of using the components of electronic marketing mix on illegal products, including digital drugs in the Saudi society. The study also showed that without electronic marketing, most illegal products (such as digital drugs) would not be marketed, as they were designed to keep pace with electronic marketing, especially over the Internet. And showed that marketers of illegal products used electronic marketing to market their products with professionalism and skill. They use the components of 
electronic marketing mix to professionally market their products, which was clarified through marketing of digital cartridges. Showed also that the marketers of illegal products used the component of the electronic product in a highly professional manner. It turned out that they produced, customized and changed the basic product as per the customer's request, and also provided the customer with products that complement the main product. The results showed that illegal product marketers also used the pricing element in a highly professional manner. They were keen to use promotional prices at first as they knew from their consumers who are mostly teenagers and young people who do not have the money to risk paying money to test products online. After trial, they raised their prices, they also offered discounts if necessary, and sometimes offered the product free at first for trial. The illegal product marketers used the component of promotion in highly efficient manner. They promoted lies and promote fraud, which was an illegal use of promotion, but they used it just as they used the entire illegal marketing, and they also used offers and gifts to promote their sales. The illegal product marketers also used the distribution component professionally, with free distribution at times, in addition to the use of the Internet as a distribution channel. In addition to the study showed that the use of electronic counter-promotion became very important as it could overcome, even slightly, the electronic marketing of such illegal products. And study showed that the spread of such illegal products over the Internet would harm the future of electronic marketing. The consumers would be banned from dealing with websites, especially as such websites might appear to offer advice or provide awareness against the use of such products, but they are originally soliciting customers for testing.

\section{The Recommendations}

1. The society must be introduced to such illegal products and educated about their harm.

2. The consumers over the Internet are to be introduced to the websites of such products.

3. Consumers need to be educated about how these illegal products use mix marketing components professionally, and that products offered to them at their request, discounted prices at the beginning or offers are just marketing ways to attract them to digital drug addiction.

4. The counter-promotion methods against websites promoting digital drugs are to be used, for promotion against these websites.

5. The websites promoting them are to be blocked and prosecuted if they are created again.

6. The websites promoting digital drugs are to be penetrated and their content is to be changed.

7. A comprehensive national plan that includes the Ministries of Health, Education, Interior and Justice is needed.

8. Legislations with severe penalties against websites promoting such drugs are to be enacted.

9. There must be participation in making a unified international law within a broad international cooperation to curb the spread of digital drugs.

\section{Limitations and Future Research}

\subsection{Limitations of Research}

There are limits to the study, where there are objective limits that focused on digital drugs out of illegal products due to the difficulty of identifying all the illegal products marketed over the Internet and the difficulty of covering them completely. Also there are geographic limits because of expansion of the Kingdom of Saudi Arabia, which makes it difficult to cover all parts of the Kingdom, it was limited to the city of Tabuk. Due to targeting the young people who use the Internet for digital drugs, the vastness of Tabuk city and the inability to cover it fully and correctly, and because the most young Internet users of university youth, the study was limited to the youth of the University of Tabuk.

\subsection{The Future Research}

- $\quad$ Research the impact of e-marketing on other illegal products

- Identify the impact of e-marketing of illegal products on licit marketers

\section{References}

Abu, S. A., Abdul, R. (2017). Use of the Internet in Digital Drug Abuse. Ministry of Interior, Sector of Technical Affairs, General department of Information and Documentation, 56-72.

Akeroyd. M. A. (2015). The effect of hearing-aid compression on judgments of relative distance. The Journal of the Acoustical Society of America, 12(2), 127-912. 
Aldridge, J., Décary-Hétu, D. (2014). Not an "Ebay for Drugs": The cryptomarket "Silk Road" as a paradigm shifting criminal innovation. The International journal of drug policy, 35(3), 58-68. https://doi.org/10.2139/ssrn.2436643

Atteya, H. (2016). Digital Drugs Inflict the Minds of Young Generations. Ad-Dustour, 28-35.

Bancroft, A., Reid, P. S. (2016). Concepts of illicit drug quality among darknet market users: Purity, embodied experience, craft and chemical knowledge. Journal of Drug Issues, 35(2), 42-49.

Barratt, M. J. (2016). Silk Road: eBay for drugs. Letter to the editor. Addiction, 107(3), 683-698. https://doi.org/10.1111/j.1360-0443.2011.03709.x

Barratt, M. J., Ferris, J. A., \& Winstock, A. R. (2016). Safer scoring? Cryptomarkets, social supply and drug market violence. International Journal of Drug Policy, 35(1), 24-31. https://doi.org/10.1016/j.drugpo.2016.04.019

Bingham, T. (2015). 'Silk Road', the virtual drug marketplace: A single case study of user experiences. Journal of Drug Issues, 24(3), 385-391.

Brady, B., \& Stevens, L. (2014). Binaural-beat induced theta EEG activity and hypnotic susceptibility. The American Journal of Clinical Hypnosis, 43(4), 69-91.

Burns, L., Roxburgh, A., Bruno, R., \& Van Buskirk, J. (2014). Monitoring drug markets in the Internet age and the evolution of drug monitoring systems in Australia. Drug Testing and Analysis, 6(1), 840-845. https://doi.org/10.1002/dta.1613

Buskirk, A. J., Van, B., Roxburgh, M., \& Farrell, L. (2017). The closure of the Silk Road: What has this meant for online drug trading? Journal of Hospital Marketing \& Public Relations, 112(2), 614-622. https://doi.org/10.1016/j.drugpo.2016.01.010

Buskirk, V. J., Roxburgh, B. A., Lenton, N. R., \& Burns, L. (2016). Characterising dark net marketplace purchasers in a sample of regular psychostimulant users. International Journal of Drug Policy, 35(4), 32-37.

Buxton, J., \& Bingham, T. (2015). The rise and challenge of dark net drug markets. Policy Brief 7. Global Drug Policy Observatory. Swansea University, Swansea, 35(3), 23-45.

Carter. C. (2015). Healthcare performance and the effects of the binaural beats on human blood pressure and heart rate. Journal of hospital marketing \& Public Relations, 18(5), 23-51.

Christin, N. (2014); Steps towards characterizing online anonymous drug marketplace customers. Addiction, 109(5), 784-785. https://doi.org/10.1111/add.12519

Christin, N. (2015). Traveling the Silk Road: A measurement analysis of a large anonymous online marketplace. In Proceedings of the 22nd International Conference on World Wide Web (pp. 213-224). New York, NY: Association for Computing Machinery.

Connolly, K. (2018). Can 'digital drugs' get you high? International Journal of Drug Policy, 27(2), 165-187.

Coomber, R., \& Maher, L. (2016). Street-level drug market activity in Sydney's primary heroin markets: Organization, adulteration practices, pricing, marketing and violence. Journal of Drug Issues, 36(3), 719-753. https://doi.org/10.1177/002204260603600310

Coomber, R., \& Moyle, L. (2014). Beyond drug dealing: Developing and extending the concept of "social supply" of illicit drugs to "minimally commercial supply." Drugs: Education, Prevention, and Policy, 21(4), 157-164. https://doi.org/10.3109/09687637.2013.798265

Crespo. A., Recuero, M., Galvez, G., \& Begona, A. (2016). Effect of Binaural Stimulation on Attention and EEG. Archives of Acoustics, 23(2), 38-71.

Curtis, R., \& Wendel, T. (2014). Toward the development of a typology of illegal drug markets. Crime Prevention Studies, 11(3), 121-152.

Décary-Hétu, D., \& Giommoni, L. (2017). Do police crackdowns disrupt drug cryptomarkets? A longitudinal analysis of the effects of operation onymous. Crime, Law and Social Change, 67(3), 55-75. https://doi.org/10.1007/s10611-016-9644-4

Demant, J., Munksgaard, R., \& Houborg, E. (2016). Personal use, social supply or redistribution? Cryptomarket demand on Silk Road 2 and Agora. Trends in Organized Crime, 12(2), 1-20. 
Dolliver, D. S. (2017). Evaluating drug trafficking on the Tor Network: Silk Road 2, the sequel. International Journal of Drug Policy, 52(4), 126-153.

Dong, M. X. (2014). Analysis of EEG activity in response to binaural beats with different frequencies. Int $J$ Psychophysiology; 94(4), 399-406.

Dunya al-Watan, R. (2018) This Is How Digital Drugs Entered the Saudi Children's Rooms. Retrieved from http://www.alwatanvoic.com/arabic/category/34.html

El Hayari, E. (2018). Damages of Digital Drugs.

El Jabouri, A. H. (2014). Conventional and Digital Drugs, Journal of the Faculty of Pharmacy. University of Babylon.

Ferris, J. A., Barratt, M. J., \& Winstock A. R. (2014). Use of Silk Road, the online drug marketplace, in the UK, Australia and the USA. Addiction, 109, 774-783. https://doi.org/10.1111/add.12470

Franceschi, L., \& Pearson, J. (2016). There's a Bitcoin bounty out on those alleged 'Evolution' Drug market scammers. Journal of Institutional Economics; 49(1), 513- 534.

Gwern, B. (2017). Black-market risks; International Journal of Drug Policy, 50(2), 183-201.

Habib, M. H. (2015). Digital Drugs between Personal Rights and Cyber Crime, Iraq. Arab Days Conference on Cybersecurity: Horizon of Cooperation for Protection of Cyberspace.

Hardy, R. A., \& Norgaard, J. R. (2016). Reputation in the Internet black market: An empirical and theoretical analysis of the Deep Web. Journal of Institutional Economics, 12(2), 515-539. https://doi.org/10.1017/S1744137415000454

Hough, M. (2014). Introduction: Illegal drug markets, research and policy. Crime prevention studies, 11(2), 1-17.

Hout, V., \& Bingham, T. (2018). Responsible vendors, intelligent consumers: Silk Road, the online revolution in drug trading. Journal of Institutional Economics, 27(4), 385-391.

Huang. T. L, \& Charyton, C. (2014). A comprehensive review of the psychological effects of brainwave entrainment. Alternative therapies in Health and Medicine, 14, 38.

Isak, L. (2017). Instantly Hooked? Freebies and Samples of Opioids, Cannabis, MDMA, and Other Drugs in an Illicit E-Commerce Market; Florida State University College of Criminology and Criminal Justice. International Journal of Drug Policy, 50(1), 657-680..

Kamphausen, T. M., Werse, B., \& Laufenberg, R. (2016). The transparency paradox. Building trust, resolving disputes and optimising logistics on conventional and online drugs markets. Alternative therapies in health and medicine, 35(1), 58-68.

Kennel, S., Taylor, A. G., Lyon, D., \& Bourguignon, C. (2014). Pilot feasibility study of binaural auditory beats for reducing symptoms of inattention in children and adolescents with attention-deficit/hyperactivity disorder. Journal of Pediatric Nursing, 25, 311.

Lenton, S., Barratt, M. J., Maddox, A., Allen, M. (2016). "What if you live on top of a bakery and you like cakes?"-Drug use and harm trajectories before, during and after the emergence of Silk Road. International Journal of Drug Policy, 35(3), 50-57.

Martin, J. (2016). Lost on the Silk Road: Online drug distribution and the 'cryptomarket'; Criminology \& Criminal Justice, 14(3), 351-367. https://doi.org/10.1177/1748895813505234

Martin, J. (2017). Drugs on the dark net. How cryptomarkets are transforming the global trade in illicit drugs. Palgrave Macmillan, Basingstoke, 26(1), 57-74.

McConnell, P. A., Froeliger, B., Garland, E. L., Ives, J. C., \& Sforzo, G. A. (2014). Auditory driving of the autonomic nervous system: Listening to theta-frequency binaural beats post-exercise increases parasympathetic activation and sympathetic withdrawal. Front Psychol, 14(5), 98-124. https://doi.org/10.3389/fpsyg.2014.01248

Morgan, K. (1970). Determining Sample Size for Research Activities. Educational and Psychological Measurement, 30(3), 607-610. https://doi.org/10.1177/001316447003000308

Ormsby, E. (2017). A week on the darknet markets - The good, the bad and the ugly. Palgrave Macmillan, Basingstoke, 27(2), 23-46.

Pratt, H., Starr, A., Michalewski, H. J., Dimitrijevic, A., Bleich, N., \& Mittelman, N. (2014). A comparison of 
auditory evoked potentials to acoustic beats and to binaural beats. Int J Psychophysiology, 26(2), 34-44.

Rouse, M. (2018). Digital drugs. International Journal of Drug Policy, 37(2), 119-132.

Smith, C. (2018). DIGITAL DRUGS: How Teens Are Using The Internet To Get 'High'. Pabst Science Publishers, 27(4), 32-49.

Tzanetakis, M. (2015). Online drug distribution: Alternatives to physical violence in conflict resolution.

Tzanetakis, M. (2018). The transparency paradox. Building trust, resolving disputes and optimising logistics on conventional and online drugs markets. The International Journal of Drug Policy, 35(3), 58-68.

\section{Copyrights}

Copyright for this article is retained by the author(s), with first publication rights granted to the journal.

This is an open-access article distributed under the terms and conditions of the Creative Commons Attribution license (http://creativecommons.org/licenses/by/4.0/). 